\title{
Business expenditures on R\&D and trade performances in Australia: Is there a link?
}

\author{
Ruhul A. Salim \\ and \\ Harry Bloch \\ School of Economics \& Finance \\ Curtin Business School (CBS) \\ Curtin University of Technology \\ Perth, WA 6845, Australia
}

Acknowledgement: This paper is out of our Tier-1(round 2, 2004) project funded by the Curtin Business School, Curtin University of Technology. Thanks to Benjamin Agbenyegah for excellent research assistance. Comments and suggestions received during the presentation of the school's seminar series are also gratefully acknowledged. 


\title{
Business expenditures on R\&D and trade performances in Australia: Is there a link?
}

\begin{abstract}
This paper empirically examines the dynamic causal link between business R\&D expenditures and trade performance in Australia. Based on cointegration and errorcorrection modeling Granger causality tests, variance decomposition and impulse response functions are used for this purpose. The results show that there is a long-run relationship exists between the trade variables and $R \& D$ expenditure and a unidirectional causality run from $\mathrm{R} \& \mathrm{D}$ expenditure to exports, imports and net exports. Further, the variance decomposition and impulse response functions confirm that a significant portion of fluctuations in the trade variables beyond the sample period is explained by $R \& D$ expenditure. Therefore, government policies that lift expenditures on business R\&D are shown to contribute to the narrowing of Australia's chronic trade deficits.
\end{abstract}

Keywords: Cointegration, error correction model, Granger causality test, generalized impulse response function.

JEL Classification: C22; F10 


\section{Business expenditures on R\&D and trade performances in Australia: Is there a link?}

\section{Introduction}

Over the past three decades, most of the world economies have undertaken marketoriented liberalization reform policies in order to boost economic performance. As a result, firms are more exposed to competition, which may motivate them to enhance research and development $(R \& D)$ expenditures. Since innovation is a major factor that determines the competitiveness of firms and economies, the extent of R\&D expenditure has important bearing on the trade performance of any economy. Growth of R\&D helps to modernize the tradable goods production, attracting domestic buyers away from imports and attracting foreign buyers to increase exports.

Several earlier studies suggest that the international price of a domestically produced trade good consists of two factors: the domestic price of good and the foreign exchange rate. R\&D plays a major role in affecting the former factor through technological innovation that reduces the domestic relative price of the good (Caves et al. 1992; Gray 1987). It has been observed that the R\&D expenditure has been increasing in Australia over the years. Similarly, both exports and imports in this country have been rising consistently though imports still outweigh exports. This paper examines the existence of short-run and long-run dynamic association between R\&D expenditure and trade performance in Australia and assesses the direction and magnitudes of causality using the vector autoregressive error-correction models.

The importance of $R \& D$ to international trade performance has been of ongoing interest to researchers. Many authors have investigated the temporal relationship between R\&D expenditures and trade performance (export and import) in recent years. Wakelin (1998) examines the role of innovation on bilateral OECD trade performance and finds, innovation proxied by $\mathrm{R} \& \mathrm{D}$ expenditure is the key variable in explaining the competitiveness of OECD countries in world trade, particularly for the US and Japan.

Gruber et al (1967) and Mansfield et al (1979) examine firm and industry-level R\&D behavior with respect to foreign markets. In general, they find that firms and 
industries have significant ongoing $R \& D$ activity because of the foreign markets they have to serve. A study by Franko (1989) concludes that R\&D intensity is a good predictor of corporate growth and the primary engine for increasing market share in global competition. His study shows that the decline in U.S. world market share of five industries during the 1970s could be attributed to a larger R\&D intensity commitment on the part of European and Japanese counterparts. Cameron, et al. (2005) maintain that R\&D plays a very significant role in raising productivity growth in UK manufacturing industries for the past the three decades (1971-1992). However, Engelbrecht (1998) argues that technology alone will not be able to overcome Australia's trade balance problems at least in the short and medium term. R\&D intensive imports still dominate exports in Australia, which implies a revealed comparative disadvantage in $R \& D$ intensive products.

Traditional analysis posits that persistent trade deficits are a consequence of macroeconomic phenomena. However, it is also argued that the deficits reflect the relative decline in Australia's global competitiveness. The popular press and some academics frequently attribute the success of several high performing Asian countries to microeconomic factors. The commitment by Japan to $R \& D$ via government approved consortiums is considered a major reason for its rapid technological development and export-led growth. ${ }^{1}$

Business expenditure on $R \& D$ is considered an important determinant of an economy's international competitiveness and specialization patterns. These expenditures are vital to create, maintain, and improve product and process innovations. In particular, such expenditures are viewed as improving existing products, creating new products and /or rationalizing production process. These factors reduce the effective costs of internally traded goods and services and thus improve the cost competitiveness of the economy, which in turn improves the trade performance.

Previous studies, such as Landermann, and Pfaffermayer (1997), Engelbrecht (1998), Basile (2001) and Aiello and Cardamone (2005), examine the role of R\&D from micro perspective (within firms and industries in relation to their foreign trade). In contrast, our research takes an alternative route by investigating from macro perspective: whether there is any short-run and long-run inter-temporal effect of business R\&D

\footnotetext{
${ }^{1}$ This opinion is emphasized by the New York Times (1993) and Dosi et al (1989)
} 
expenditures on aggregate trade performance (exports as well as imports) of Australia. While this is theoretically sound, an empirical linkage should be investigated and established. This paper proceeds in the spirit of Kouassi, et al. (1999) and Narayan and Smyth (2005), who test for temporal causality between terms of trade and current account deficit in the former case and among democracy, emigration and real income in the latter case.

The rest of the paper is organized as follows. The next section provides an overview of R\&D expenditure in Australia, followed by a description of the econometric methodology employed in this paper. Section 4 reviews data and their time-series properties, followed by results from the estimation. Conclusions and policy implications are given in the final section.

\section{An Overview of Australia's R\&D Expenditure}

Australia's expenditures on $R \& D$, particularly business $R \& D$ expenditures, have increased steadily since the mid 1970s. For example, in 1975-76 business R\&D expenditures were meager $\$ 875$ thousands, while the figure reaches to approximately \$6 billion in 2003-04 (ABS). This tremendous growth of business R\&D expenditure follows implementation of various government policies in the 1980s and early 1990s, such as policies related to increased human capital formation and integration with the global economy through trade liberalization.

Despite the sound economic growth over the past decade business expenditures on R\&D remains very low in Australia. In 2003-04, it was estimated to be $\$ 7,220$ million at current prices, 10 percent higher than that recorded in 2002-03. This is the highest level recorded and is the fourth successive year of increase following the declines from 1995-96 to 1998-99 and the leveling off between 1998-99 and 1999-2000. The fall in business R\&D is linked to the coalition government's cut in a tax concession for R\&D in industry. However, government's policies have been changed at the beginning of the new millennium. Therefore, there is an upward trend in business expenditures on R\&D since 2001. However, Australia's R\&D intensity (ratio of R\&D expenditure to GDP) still 
remains low compared to other OECD countries. ${ }^{2}$ Unlike other developed countries which focus most of their R\&D expenditure efforts on manufacturing, Australia spends mainly in primary products, mining and primary-products related industries. Australia's business R\&D to GDP has been hovering around 1 percent in the 1990s, since then it remained steady. However, the total R\&D expenditures (both private and public) have been driven up to $1.6 \%$ of GDP. The average annual real increase in business expenditure on R\&D is over 10 percent since 1998-99 in Australia which is significantly higher than that of 5 percent in OECD countries. This has been achieved through a number of measures, such as cooperative joint venture research and easing of regulations for the development of ventures business, etc.

Further policies aimed directly at technological innovation, such as the $150 \%$ R\&D tax allowance, the government's procurement and the partnership for development program. Overall, there has been a clear government-led science and technology push, as reflected in the current government's Backing Australia's Ability statement, for the structural change of the Australian economy towards enhancing non-traditional exports.

\section{Econometric Methodology}

A voluminous studies has evolved after the seminal works of Granger (1969) and Sims (1972) on determining causality among macro variables such as money, income and interest rates; money, output and inflation; output, exports and exchange rates; output, consumption and prices; etc. However, the causal chain among trade variables and R\&D expenditure has received less attention and still remains relatively unexplored.

Economic theory provides limited guidance for the modeling of the short-run and long-run dynamics of R\&D outlays and the components of trade balance. Hence, we adopt a modeling strategy that emphasizes the information provided by the time-series properties of the data. Recent developments in the theory of cointegration by Engle and Granger (1987) provide new techniques of testing dynamic linkages between variables. Granger (1988) claims that a prerequisite for two variables to establish a long-run equilibrium relationship is the existence of a dynamic causal relationship between them. Such a dynamic causal association of variables is a reflection of their short-run relationship.

\footnotetext{
${ }^{2}$ In terms of R\&D intensity Australia ranks below Japan (3\%), Sweden (3.8\%), Canada (1.8\%), Germany (2.5\%), UK (2\%) and most other OECD countries in 2003-04 (Source: OECD, Main Science and Technology Indicators)
} 
Engle and Granger (1987) showed that if two variables are cointegrated then the variables follow a well-specified error-correction model. The error-correction term in this model stands for the short-run adjustment to long-term equilibrium trends. Therefore, the error-correction model provides a means of testing the dynamic relationship between the two variables. Hence, an econometric definition by dynamic association or causality between variables, as suggested by Granger (i.e. Granger causality), will be the major point of this empirical investigation. Vector Autoregressive Model (VAR), popularized by Sims (1980) will be applied in this study. Given the presence of potential two-way relationships between R\&D expenditures and trade variables, the estimation of a VAR model to test causality hypotheses is more reliable than that of a single equation model. VAR systems treat all variables as endogenous avoiding thus infecting the model with false identifying restrictions (Sims, 1980). Beyond Granger causality tests, this study explores the effects shocks in each variable beyond the sample period through variance decomposition and impulse response functions.

The decomposition of variance analysis offers a sophisticated technique for examining the VAR system dynamics that helps to determine the relative strength of the Granger causality. The advantage of using variance decomposition lies in its ability to provide information about the relative importance of random innovations. In particular, it is able to provide information on the percentage of variation in the forecast error of a variable explained by its own innovations and the proportion explained by innovations in other variables in the system through the dynamic structure of the VAR. Sims (1980) notes that if a variable is truly exogenous with respect to the other variables in the system, own innovations will explain all of the variables' forecast error variance. Finally, impulse response functions are introduced here to trace out the responsiveness of the dependent variables in the VAR to shocks to each of the variables.

\section{Data and Time-Series Properties}

This study uses quarterly data for the period 1975:1 to 2002:4. Time series data on R\&D

expenditure are obtained from the Australian Bureau of Statistics (ABS), while export and import data are from the World Development Indicators published by the World Bank. The ABS Survey of R\&D in the business sector is conducted in accordance with standard guidelines promulgated by the Organization for Economic Co-operation and Development 
(OECD). Where quarterly observations are not available, figures are obtained by using the Lisman and Sandee (1964) method. Variables used here are exports (EXP), imports (IMP), NEXP (export-import ratio) and business R\&D expenditures (BR\&D). All the analysis is carried out using the natural logs of variables in question.

Table 1: Unit Root Tests

\begin{tabular}{|c|c|c|c|c|}
\hline \multirow[t]{2}{*}{ Variables } & \multicolumn{2}{|l|}{$\mathrm{ADF}$} & \multicolumn{2}{|l|}{$\mathrm{PP}$} \\
\hline & No Trend & Trend & No Trend & Trend \\
\hline \multicolumn{5}{|c|}{ Levels series } \\
\hline LBR\&D & $-1.207178[4]$ & $-1.150582[4]$ & $-1.39792[5]$ & $-1.179878[3]$ \\
\hline LEXP & $-0.076165[5]$ & $-2.265456[3]$ & $-0.35234[6]$ & $-1.701549[4]$ \\
\hline LIMP & $0.639424[6]$ & $-2.474197[4]$ & $0.19270[4]$ & $-2.643234[3]$ \\
\hline LNEXP & $-2.202893[2]$ & $3.319311[3]$ & $-2.6180[3]$ & $-2.593205[4]$ \\
\hline \multicolumn{5}{|c|}{ First differenced series } \\
\hline$\triangle \mathrm{LBR} \& \mathrm{D}$ & -4.410267 & -4.522191 & -11.56439 & -11.64132 \\
\hline$\triangle \mathrm{LEXP}$ & -3.592922 & -3.573537 & -3.831365 & -3.815547 \\
\hline$\Delta$ LIMP & -4.684727 & -3.474197 & 0.19270 & -4.155066 \\
\hline$\triangle \mathrm{LNEXP}$ & -4.388174 & -4.418248 & -4.030048 & -4.030573 \\
\hline \multicolumn{5}{|c|}{$\begin{array}{l}\text { Critical values (level } \\
\text { series) }\end{array}$} \\
\hline $1 \%$ & -3.4922 & -4.0468 & -3.4900 & -4.0429 \\
\hline $5 \%$ & -2.8884 & -3.4519 & -2.8874 & -3.4504 \\
\hline \multicolumn{5}{|c|}{$\begin{array}{l}\text { Critical values (First } \\
\text { differenced series) }\end{array}$} \\
\hline $1 \%$ & -3.4928 & -4.0468 & -3.4906 & -4.0437 \\
\hline $5 \%$ & -2.8887 & -3.4523 & -2.8877 & -3.4508 \\
\hline
\end{tabular}

Notes: Critical values from Mackinnon (1991). Figures in the parenthesis represent the optimal lag length determined by Schwartz Information Criterion. The bandwidth is selected following the Newey-West Criterion; and the spectral estimation is based on the Bartlett Kernel method.

To provide valid empirical evidence on long-run relationship between variables it is imperative to test the time-series properties of the variables in question. Unit root tests identify whether the variables are stationary or non-stationary. There are a number of tests developed in the time-series econometrics for testing for the presence of unit roots. This study uses two most popular tests, namely the Augmented Dickey-Fuller $(A D F)$ and the 
Phillips-Peron $(P P)$ tests in testing for unit roots in exports, imports, net exports and business R\&D expenditure variables. These tests are applied to both the original series (in logarithmic form) and to the first differences. Further, models either with or without trend are tried. The results are reported in Table 1.

The ADF and PP statistics for levels series of business R\&D, exports, imports and export-import ratio do not exceed their critical values (in absolute terms) at $5 \%$ level of significance. Therefore, these variables are not stationary in level. However, both ADF and PP tests exceed their corresponding critical values at 5\% level of significance when the variables are first differenced. Thus, the null hypothesis of the presence of a unit root in these variables is rejected, which imply that these variables are stationary in first differences and therefore integrated in order 1, i.e. I(1).

\section{Analysis of Empirical Results}

The empirical analysis reported here is based on two-stage estimation. In the first stage, cointegration analysis is used to identify conintegrating relationships among these variables. This is important because if two nonstationary variables are cointegrated, a VAR model in the first difference is misspecified. If cointegration relationship is identified, the model should include residuals from the vectors (lagged one period) in the dynamic VECM system.

\section{Identification of Cointegration Relationship}

Tests for cointegrating relationship between variables are conducted using the Johansen cointegration technique. The test results for the order of integration of the basic set of variables have been obtained using the Johansen procedure, which has a well-defined limiting distribution. The tests for the order of integration do not suffer from parameter instability associated with the DF and ADF tests and are consistent with the use of the Johansen procedure to estimate the cointegrating vectors. The test statistics and asymptotic $95 \%$ and $99 \%$ critical values are shown in Table 2.

In order to carry out the cointegration test, the Schwartz information criterion is used to select the optimal lag length i.e. the order of the VAR model. This criterion suggests a VAR of order of 4 , but since there is flexibility in the selection criteria and due to the nature of data used in this study a VAR of order 7 is used for exports (LEXP) and 
business R\&D (LBR\&D) as well as imports (LIMP) and business R\&D (LBR\&D), while a VAR of 3 for exports-imports ratio (LNEXP) and business R\&D (LBR\&D) is used.

Table 2: Johansen's Cointegration Test

\begin{tabular}{ccccccc}
\hline \multirow{2}{*}{ Vector } & $\begin{array}{c}\text { Null } \\
\text { Hypothesis }\end{array}$ & $\begin{array}{c}\text { Alternative } \\
\text { Hypothesis }\end{array}$ & Eigenvalue & $\begin{array}{c}\text { Trace } \\
\text { Statistic }\end{array}$ & \multicolumn{2}{c}{ Critical Value } \\
\cline { 6 - 7 } & & & & & $5 \%$ & $1 \%$ \\
\hline LEXP LBR\&D & $\mathrm{r}=0^{* *}$ & $\mathrm{r}=1$ & 0.148481 & 20.57658 & 15.41 & 20.04 \\
& $\mathrm{r}<=1^{*}$ & $\mathrm{r}=2$ & 0.036438 & 3.860271 & 3.76 & 6.65 \\
LIMP LBR\&D & $\mathrm{r}=0^{*}$ & $\mathrm{r}=1$ & 0.123068 & 15.74503 & 15.41 & 20.04 \\
& $\mathrm{r}<=1$ & $\mathrm{r}=2$ & 0.019868 & 2.087111 & 3.76 & 6.65 \\
LNEXP LBR\&D & $\mathrm{r}=0^{* *}$ & $\mathrm{r}=1$ & 0.190876 & 24.46023 & 15.41 & 20.04 \\
& $\mathrm{r}<=1$ & $\mathrm{r}=2$ & 0.014573 & 1.585489 & 3.76 & 6.65 \\
\hline
\end{tabular}

Note: $*(* *)$ denotes rejection of the null hypothesis at the $5 \%(1 \%)$ level.

The Johansen test statistics for LEXP and LBR\&D vectors show rejection for the null hypothesis of no cointegrating vectors under both the trace and maximal eigenvalue. In the case of the trace test, the null of no cointegrating vectors is rejected since the test statistic of 20.57658 is greater than the $1 \%$ and $5 \%$ critical values of 20.04 and 15.41 , respectively. Moving on to test the null of at most 1 cointegrating vectors, the trace statistic is 3.86 , while the $5 \%$ critical value is 3.76 , so the null is just rejected at $5 \%$ (and not rejected at $1 \%$ ). Therefore, there is at least one cointegrating vector between exports and business R\&D.

The maximal eigenvalue test for LIMP and LBR\&D of the null hypothesis that there are no cointegrating vectors against the alternative of 1 and at most 1 against the alternative of more than 1 cointegrating vectors are rejected both at $1 \%$ and $5 \%$ level of significance. However, the Johansen test suggest that the null hypothesis of no cointegrating vector is just rejected at $5 \%$ level (not at $1 \%$ percent level). The other null hypothesis cannot be rejected. This indicates that there is at most one cointegrating vector between imports and business R\&D. Similarly, the Johansen trace statistic for LNEXP and LBR\&D the null hypothesis of no cointegrating vector is rejected both at $5 \%$ and $1 \%$ level of significance suggests that there is at least 1 cointegrating vector (reference Table 2). 
Vector Error-correction Model and Granger Causality Test

We find that the variables in question are stationary and there is at least one cointegrating vector for each pair-wise relationship. However, cointegration does not detect the direction of Granger causality among variables. Therefore, vector error-correction models (VECM) are estimated in order to find the direction of causality. The included lagged errorcorrection term in the VECM provides an additional channel of Granger causality. To test the effects of independent variables including all lagged variables, the $F$-test framework is used. These tests are referred to as Granger causality tests.

The summary of the pair-wise Granger causality tests are reported in Table 3. These results indicate that business R\&D Granger-causes exports, imports and exportimport ratio, as the null hypotheses are rejected at least at the 5\% level of significance in each of these cases. The test results also indicate a non-rejection of the null hypothesis at $5 \%$ level of significance in the case of export, import and export-import ratio suggesting that business R\&D is not Granger caused by exports, imports or the export-import ratio.

Table 3: $F$-statistics for Tests of Granger Causality Based on VECM

\begin{tabular}{lcc}
\hline Null Hypotheses: & $F$-statistics & Probability \\
\hline LBR\&D does not Granger cause LEXP & 5.07938 & 0.00784 \\
LEXP does not Granger cause LBR\&D & 1.02817 & 036123 \\
LBR\&D does not Granger cause LIMP & 5.03899 & 0.00813 \\
LIMP does not Granger cause LBR\&D & 0.49268 & 0.61239 \\
LNBR\&D does not Granger cause LNEXP & 3.41710 & 0.03650 \\
LNEXP does not Granger cause LBR\&D & 0.38352 & 068241
\end{tabular}

Note: The vector error-correction model (VECM) is based on an optimally determined (Schwartz Information Criterion) lag structure and a constant.

\section{Test of Source of Variability}

The Granger causality tests suggest that business R\&D has significant impact on exports, imports and export-import ratio. However, the $F$-tests fail to explain the sign of the relationship between variables (such as export and business R\&D) or how long these effects require to take place. In other words, $F$-test results do not reveal whether the change in any given variable has a positive or negative effect on other variables in the 
system. Neither do the $F$-test results indicate how long it would take for the effect of that variable to work through the system. The variance decomposition and VAR impulse response functions provide such information.

\section{Variance Decomposition}

The variance decomposition provides the proportion of the movement in the dependent variables that is due to their 'own' shocks versus shocks to the other variables. The results of the variance decomposition over a 40-quarter time horizon are presented in Tables 4-6. The results indicate that disturbances originating from exports lead to the greatest variability to future exports; they contribute about $75 \%$ for the 12 quarters ( 3 years) ahead while business R\&D contributes only $25 \%$ to the variation of exports. The proportion of variance in future exports due to its own innovation declines gradually, but it remains about $33 \%$ until 40 quarters (10 years). This implies that business R\&D contributes about $67 \%$ to the future exports after 10 years. The results (Table 6) also show that a substantial portion of the variances of business R\&D is explained by its own innovations, such as $92 \%$ in 10 -quarter, $84 \%$ in 20 -quarter and about $80 \%$ in 40 -quarter periods respectively. This implies that exports explain very little portion of variation in business R\&D even in the long-run.

Table 4: Variance Decomposition of Exports and Bus R\&D

\begin{tabular}{lccccccc}
\hline & \multicolumn{3}{c}{ Variance Decomposition of EXP } & \multicolumn{4}{c}{ Variance Decomposition of BR\&D } \\
\cline { 2 - 8 } Period & S.E. & EXP & BR\&D & Period & S.E. & EXP & BR\&D \\
\hline 1 & 0.007956 & 100.0000 & 0.000000 & 1 & 0.072690 & 1.107292 & 98.89271 \\
10 & 0.065434 & 85.54876 & 14.45124 & 10 & 0.192969 & 7.44693 & 92.55307 \\
12 & 0.074946 & 75.72411 & 24.27589 & 12 & 0.212005 & 10.59470 & 89.40530 \\
20 & 0.091007 & 59.09079 & 40.34485 & 20 & 0.243103 & 15.91827 & 84.08173 \\
30 & 0.109391 & 41.41249 & 58.58751 & 30 & 0.275301 & 18.273097 & 81.72690 \\
40 & 0.123127 & 32.82335 & 67.17665 & 40 & 0.301715 & 20.398754 & 79.60125 \\
\hline
\end{tabular}

Note: The decompositions are reported for one-, ten-, twelve-, twenty-, thirty- and forty-quarter horizons. Ordering used here is LEXP LBR\&D. However, changing the order did not alter the results to any substantial degree. This is because Choleski decomposition is used in order to orthogonalize the innovations across equations.

The results reported in Table 5 show that even after 10-quarter horizon about $92 \%$ of the variation in imports is explained by its own shocks and the rest $8 \%$ is explained by the 
innovations of business R\&D. As time elapses into the long run, say 40-quarter horizon, about $48 \%$ of the forecast error for import is explained by its own innovations and about $52 \%$ is explained by the innovation of business R\&D. In case of business R\&D, even after 20-quarter horizon, about $96 \%$ variation in the forecast error for is explained by its own innovations and only $4 \%$ is explained by the innovation of imports. As time elapses into the long run, about $92 \%$ of the variation in the forecast error for business R\&D is explained by its own innovations and only about $8 \%$ is explained by the innovation of import.

\section{Table 5: Variance Decomposition of Imports and Bus R\&D}

\begin{tabular}{lccccccc}
\hline & \multicolumn{3}{c}{ Variance Decomposition of IMP } & \multicolumn{4}{c}{ Variance Decomposition of BR\&D } \\
\cline { 2 - 5 } Period & S.E. & IMP & BR\&D & Period & S.E. & IMP & BR\&D \\
\hline 1 & 0.014836 & 100.0000 & 0.000000 & 1 & 0.073056 & 0.013494 & 99.98651 \\
10 & 0.111475 & 92.26156 & 7.738440 & 10 & 0.198948 & 2.530997 & 97.46900 \\
12 & 0.127924 & 80.84714 & 19.15286 & 12 & 0.235055 & 3.451622 & 96.54838 \\
20 & 0.138643 & 69.32211 & 30.67789 & 20 & 0.263056 & 4.103434 & 95.89657 \\
30 & 0.156048 & 55.23026 & 44.76974 & 30 & 0.307200 & 6.590877 & 93.40912 \\
40 & 0.168434 & 47.55497 & 52.44503 & 40 & 0.341887 & 8.322431 & 91.67757
\end{tabular}

Note: The decompositions are reported for one-, ten-, twelve-, twenty-, thirty- and forty-quarter horizons. Ordering used here is LIMP LBR\&D. However, changing the order did not alter the results to any substantial degree. This is because Choleski decomposition is used in order to orthogonalize the innovations across equations.

Table 6: Variance Decomposition of Net Exports and Bus R\&D

\begin{tabular}{cccccccc}
\hline \multicolumn{3}{c}{ Variance Decomposition of LNEXP } & \multicolumn{4}{c}{ Variance Decomposition of BR\&D } \\
Period & S.E. & NEXP & BR\&D & Period & S.E. & NEXP & BR\&D \\
\cline { 2 - 6 } 1 & 0.015246 & 100.0000 & 0.000000 & 1 & 0.073131 & 0.001376 & 99.99862 \\
10 & 0.071790 & 99.37345 & 0.626555 & 10 & 0.201218 & 1.946767 & 98.05323 \\
12 & 0.079534 & 99.08341 & 0.916590 & 12 & 0.241540 & 2.143449 & 97.85655 \\
20 & 0.080631 & 98.98723 & 1.012767 & 20 & 0.273255 & 3.882325 & 96.11767 \\
30 & 0.082729 & 98.62008 & 1.379918 & 30 & 0.322719 & 5.938880 & 94.06112 \\
40 & 0.083206 & 98.34341 & 1.656595 & 40 & 0.359912 & 6.878184 & 93.12182 \\
\hline
\end{tabular}

Note: Same as Table 5. 
The results presented in Table 6 show that about $99 \%$ of the shocks in export-import ratio at the 12-quarter horizon are accounted for by its own shock and the remaining $1 \%$ is explained by business R\&D. As time elapses into long-run, say up to 40-quarter horizon the variation in the forecast error for export-import ratio is substantially explained by its own innovations and only about $2 \%$ is explained by the innovation of bus R\&D. By similar fashion, about $98 \%$ of the variation in the forecast error for business R\&D is explained by its own innovations and only about $2 \%$ is explained by the innovation of export-import ratio for the 12 quarter period. As time elapses into the long run, about $93 \%$ of the variation in the forecast error for business $R \& D$ is explained by its own innovations and only about $7 \%$ is explained by the innovation of export-import ratio.

\section{Impulse Response Function}

The orthogonalized impulse response functions provide a slightly different method for examining the VAR system dynamics. Basically, they trace out the responsiveness of the dependent variables in the VAR to shocks to each of the variables in the model. The results of the impulse response of the variables are presented in Figures 3-8.

Figure: 3: Response from exports

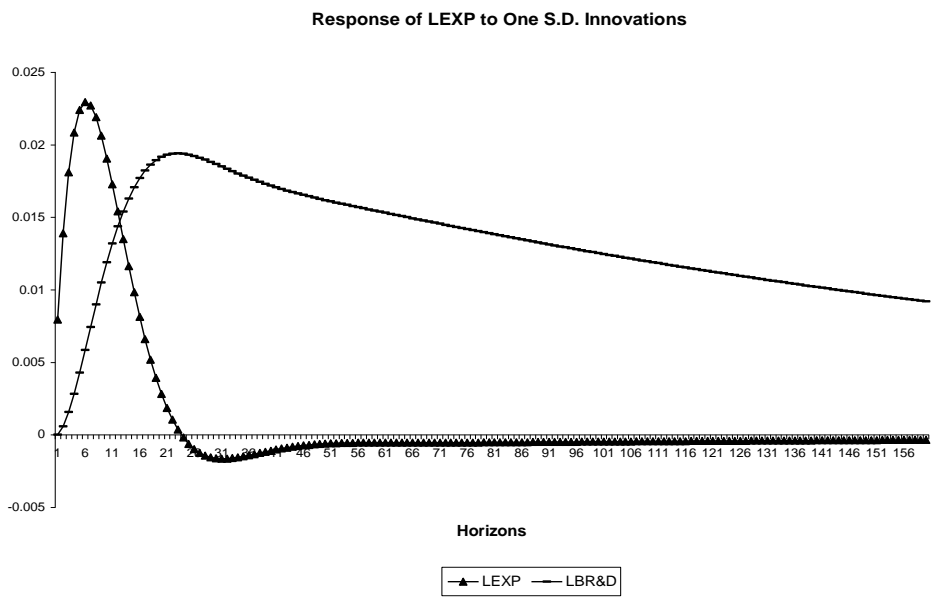

In response to a unit standard error (SE) shock in exports (Figure 3), future exports increase just over $2 \%$ and then decline gradually until dying out after the $23^{\text {rd }}$ period. However, the response of exports to a unit SE shock in business R\&D has persistence effects and does not generally die out. Exports' response to a unit SE shock in business 
$R \& D$ increases up to the $26^{\text {th }}$ period horizon and then decreases, remaining positive throughout. A unit shock originating from business R\&D (Figure 4) produces up to 7\% increase in exports in the first quarter and, while declining quickly, persists in the long run. However, a unit shock of business R\&D in itself is negative until $26^{\text {th }}$ quarter, remaining at zero thereafter.

Figure 4: Response from business R\&D

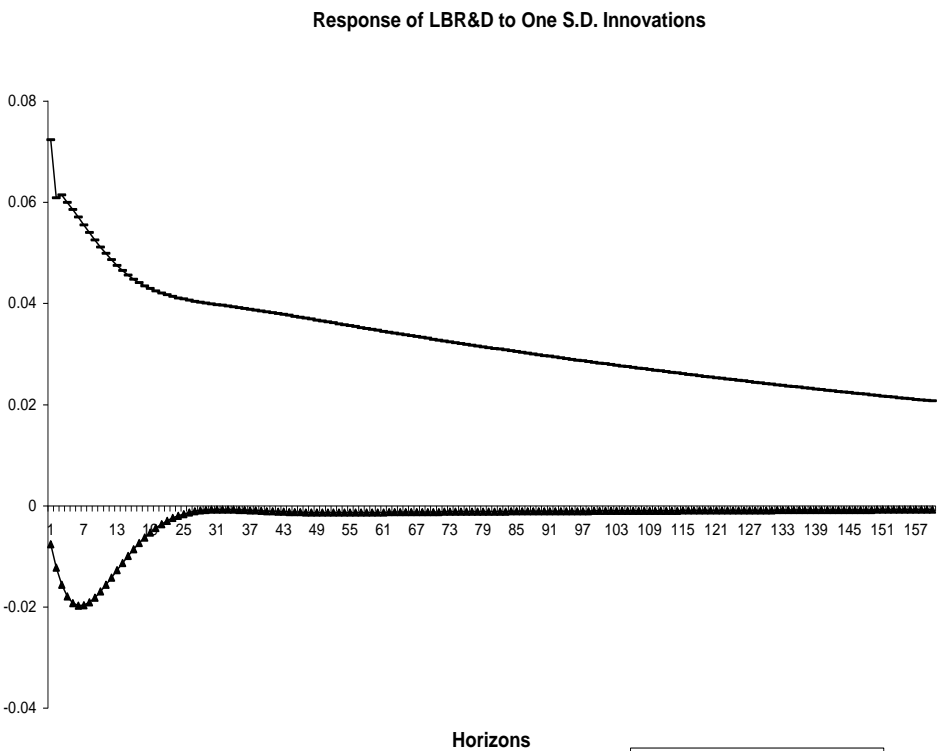

Figure 5: Response from imports

Response of LIMP to One S.D. Innovations

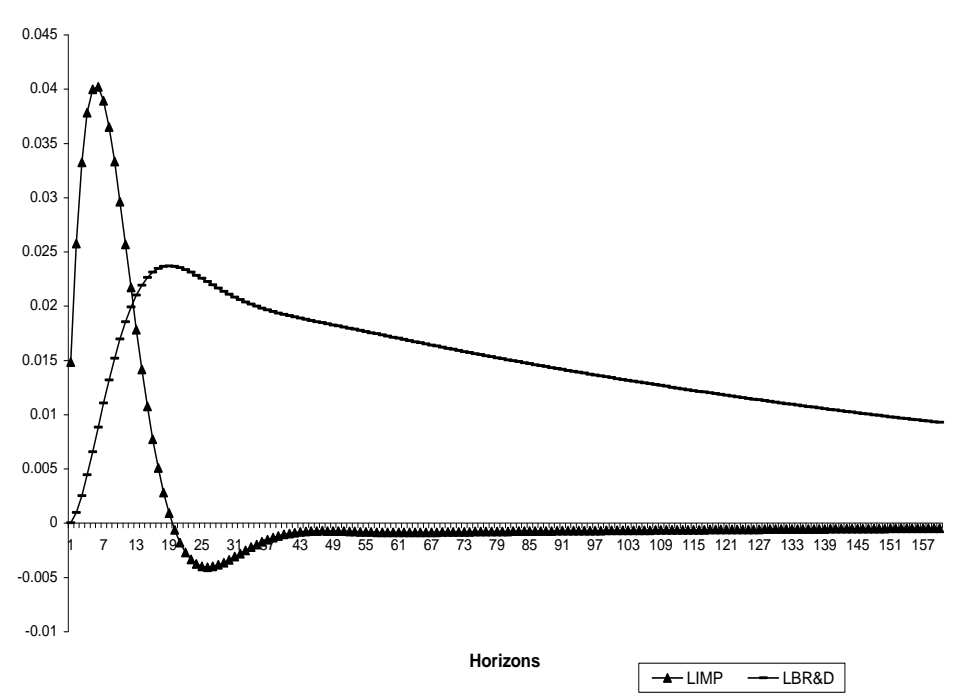


The results reported in Figure 5 indicate that the response of imports to a unit standard error shock in itself is $1.5 \%$ in the first quarter, rising to $4 \%$ in the $7^{\text {th }}$ quarter and then gradually declining until dying out. This implies that the speed of adjustment is very fast. The response of business $R \& D$ to a unit SE shock in imports has persistence effects and does not generally die out.

Figure 6: Response from business $R \& D$

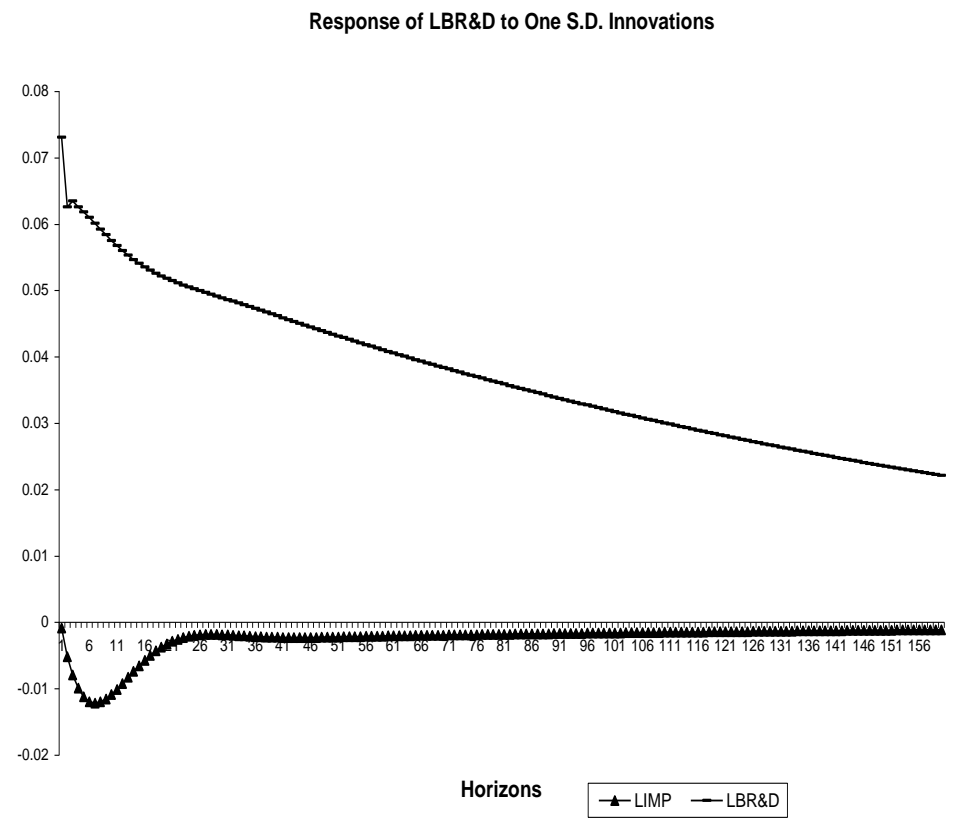

In Figure 6, the response of business R\&D to a unit SE shock in imports is positive throughout and, although declining, does not die out. The response of business R\&D to a unit SE shock to itself is negative up to $80^{\text {th }}$ quarter and then reaches to zero for the rest of the period of horizons considered for this test.

A one unit SE shock originating from export-import ratio itself (Figure 7) results in an approximately $1.5 \%$ increases in the first quarter, rising to $3.5 \%$ in the $5^{\text {th }}$ quarter. The adjustment, however, undergoes reversal $(-1 \%$, almost $2 \%)$ between the $8^{\text {th }}$ and $15^{\text {th }}$ quarter. The response of business $\mathrm{R} \& \mathrm{D}$ to a unit SE shock in the export-import ratio is very small and dies out in the long-run. Finally, a unit SE shock originating from business R\&D to export-import ratio results in an approximately $7 \%$ rise (Figure 8 ) in the first quarter and then steadily declines while persisting up to the long run. However, the responses of business R\&D to a unit SE shock in itself (Figure 8) is small, starting from 
zero in the first quarter reaches to just over $1 \%$ in the $7^{\text {th }}$ quarter, and then fluctuates a little between the $10^{\text {th }}$ and $40^{\text {th }}$ quarter before dying out in the long-run.

Figure 7: Response from export-import ratio

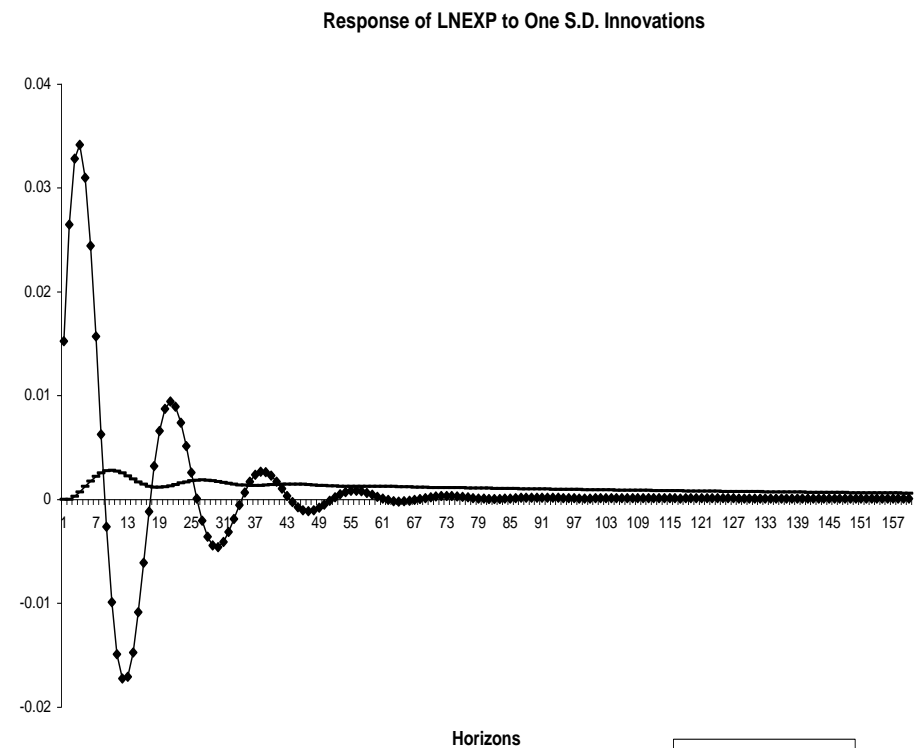

Figure 8: Response from business R\&D

Response of LBR\&D to One S.D. Innovations

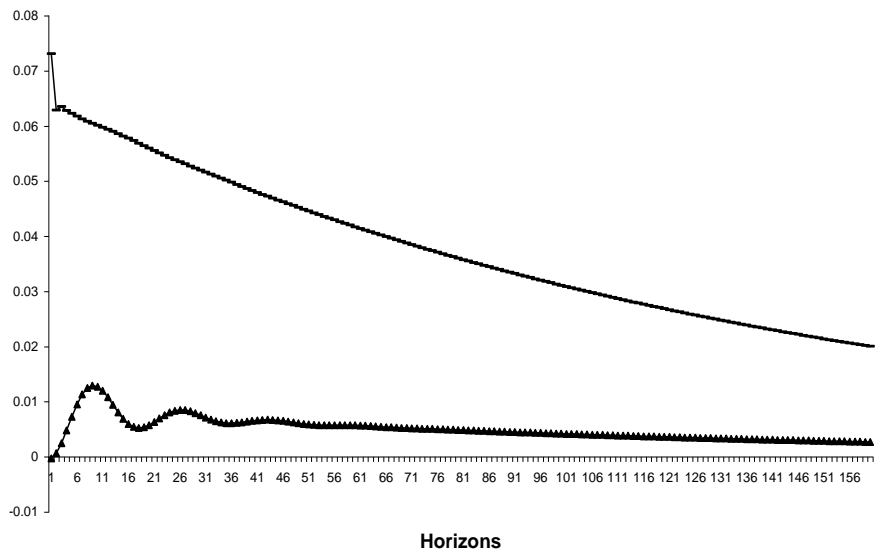

$\rightarrow$ LNEXP - - LBR\&D

The test results of the variance decomposition and impulse response functions, with the exception of the results for the export-import ratio and business $R \& D$, are consistent with the results of Granger causality test. The impulse response functions in this 
study gradually decline, but do not die out in the cases of exports to itself, business R\&D to exports and imports, imports to business R\&D and the export-import ratio to business R\&D. Rather, the effect of shocks for these cases persist into the long-run.

\section{Conclusions and policy implications}

This paper applies cointegration and vector error-correction models to explain the causal relationship between business $R \& D$ expenditure and trade performance in Australia. The main contribution of this paper is to address the issue of short-run dynamics of business expenditure on R\&D and trade performance within a long-run framework. The results of the cointegration analysis show that R\&D expenditures, exports, imports and exportimport ratio are cointegrated, indicating that there is a stable long run relationship between them. The results of causality analysis show that business R\&D Granger causes exports, imports and net exports, which suggests that business R\&D has important consequences for trade performance in Australia. Furthermore, the effects to shocks in business R\&D in exports, imports and net exports are shown have strong persistence, so that they cannot be dismissed as purely short-run phenomena.

We find that innovations in business $R \& D$ expenditure have positive and persistently impact on both exports and imports, so that trade activity is enhanced in both the short and long run. Such impacts are positive for economic well being when increased integration into the world economy is viewed as promoting competition and increased choice of product varieties. Further, we find that the impacts are not totally offsetting, with net exports also positively and persistently impacted by shocks to business R\&D. Thus, government policies that lift expenditures on business $R \& D$ are shown to contribute to the narrowing of Australia's chronic trade deficits. 


\section{References}

Aiello, F. and Cardamone, P. (2005), R\&D spillovers and productivity growth: evidence from Italian manufacturing microdata, Applied Economics Letter, 12: 625-31.

Australian Bureau of Statistics (ABS), Australia's R\&D indicators in international context (several issues).

Basile, R. (2001) Export behavior of Italian manufacturing firms over the nineties: the role of innovation, Research Policy, 30: 1185-1201.

Cameron, G., Proudman, J. and Redding, S. (2005) Technology Transfer, R\&D, Trade and Productivity Growth', European Economic Review, 49, 3, 775-807.

Caves, Richard E. et al. (1992), Industrial Efficiency in Six Nations, Cambridge, MA, MIT Press

Dosi, G., Pavitt, K. and Soete, L. (1990), The Economics of Technological Change and International Trade, Harvester Wheattsheaf Publishers, Brighton, USA

Engelbrecht, Hans-Jürgen (1998), Business sector R\&D and Australia's manufacturing trade structure, Applied Economics, 30: 177-87.

Engle, R. F. and Granger, C. W. J. (1987), Cointegration and error-correction: representation, estimation and testing, Econometrica, 55: 251-76.

Engle, R.F., and C.W.J. Granger. (1987), Co-integration and Error Correction: Representation, Estimation, and Testing. Econometrica 55:251-76.

Franko, I. G. (1989) Global corporate competition: Who's winning, who's losing, and the R\&D factor as one reason why, Strategic Management Journal, 10: 449-474.

Granger, C. W. J. (1969), Investigating causal relationship by econometric models and cross-spectral methods, Econometrica, 37: 424-38.

Granger, C. W. J. (1988), Some recent developments in a concept of causality, Journal of Econometrics, 39: 192-211.

Gray, R.W., (1987), Why does futures trading succeed or fail: an analysis of selected commodities, in A.E. Peck, ed: Readings in Futures Markets (volume 3. Chicago: Chicago Board of Trade, pp.235-248).

Gruber, W., Mehta, D. and Vernon, R. H. G. (1967) The R\&D factor in international trade and international investment of the United States industries, Journal of Political Economy, 75: 20-37.

Kouassi E., Decaluwe B., Kapombe C. M. and Colyer D. (1999), Temporal causality and the dynamic interactions between terms of trade and current account deficits in cointegrated VAR process: further evidence from Ivorian time series, Applied Economics, 31: 89-96.

Landermann, M. and Pfaffermayer, M. (1997) Technological competition and trade performance, Applied Economics, 29: 1979-96. 
Lisman, J.H.C. and J. Sandee (1964) Derivation of quarterly figures from annual data Applied Statistics, 13: 87-90.

MacKinnon, J. (1991) Critical Values for Cointegration Tests, in R. F. Engle \& C. W. J. Granger (Eds) Long-run Economic Relationships: Readings in Cointegration, Oxford University Press.

Mansfield, E. Romeo, A. and Wagner, S. (1979) Foreign trade and US research and development, The Review of Economics and Statistics, 61: 49-57.

Narayan, P. K. and Smyth, R. (2005), Temporal causality and the dynamics of democracy, emigration and real income in Fiji, International Review of Applied Economics, 19: 245-63.

New York Times, (1993) Japanese Display Technology, August.

OECD (2004), OECD, main science and technology indicators.

Sims, A. C. (1980), Macroeconomics and Reality, Econometrica, 48: 1-48.

Sims, C. A. (1972), Money, income and causality, American Economic Review, 62: 54052.

Wakelin, K. (1998) The Role of Innovation in Bilateral OECD Trade Performance. Applied Economics, 30, pp. 1335-1346. 